\title{
Association of CD69 Up-Regulation on CD4+ CLA+ T Cells Versus Patch Test, Strip Patch Test and Clinical History in Nickel SENSitization
}

\author{
H. Dickel ${ }^{1}$, O. Kuss ${ }^{2}$, J. Kamphowe ${ }^{1}$, P. Altmeyer ${ }^{1}$, S. Höxtermann ${ }^{1}$ \\ ${ }^{1}$ Department of Dermatology and Allergology, Ruhr University Bochum, Bochum, Germany, \\ ${ }^{2}$ Institute of Medical Epidemiology, Biostatistics, and Informatics, Martin Luther University of Halle-Wittenberg, Halle (Saale), \\ Germany
}

\begin{abstract}
Objective: The patch test (PT) with its modification the strip patch test (SPT) - is the standard in vivo procedure to diagnose an allergic contact dermatitis (ACD). To date, none of the in vitro tests for the diagnosis of ACD fulfils the requirements of an easy, valid and reliable test. To investigate the prediction ability of a flow cytometric assay of CD69 up-regulation on CD4+ CLA+ T cells in nickel-sensitive and non-nickel-sensitive patients.

Methods: In a prospective, investigator-blinded, clinical study a total of 85 nickel-sensitive $(n=44 ; 51.8 \%)$ and non-nickel-sensitive patients ( $\mathrm{n}=41 ; 48.2 \%$ ) were enrolled. The association between CD69 up-regulation on CD4+ CLA+ T cells on the one hand and PT, SPT, and clinical history on the other hand was measured. Association is expressed with c statistic values (receiver operating characteristic analysis) and corresponding 95\% CIs.

Results: The associations were $\mathrm{c}=0.57$ (95\% CI: 0.42-0.72) between CD69 up-regulation and PT, c = 0.49 (95\% CI: 0.36-0.62) between CD69 up-regulation and SPT, and c $=0.51$ (95\% CI: 0.37-0.64) between CD69 up-regulation and clinical history.

Conclusions: CD69 up-regulation on CD4+ CLA+ T cells in vitro could not predict neither a positive PT or SPT result nor a positive clinical history to nickel sulfate. The combination of clinical history and patch testing still remains the basis for diagnosing ACD.
\end{abstract}

Key words: Allergic contact dermatitis, nickel sulfate, flow cytometric assay, CD69 up-regulation, patch test, strip patch test, clinical history, receiver operating characteristic

Abbreviations: $\mathrm{ACD}=$ Allergic contact dermatitis; $\mathrm{AI}$ $=$ Activation index; $\mathrm{CD}=$ Cluster of differentiation; $\mathrm{CI}=$ Confidence interval; CLA = Cutaneous lymphocyte-associated antigen; D-PBS = Dulbecco's phosphate-buffered saline; DC $=$ Dendritic cells; DTS = Delayed-type sensitization; ELISpot = Enzym-linked immunospot; FACS = Fluorescence-activated cell sorting; LT'T $=$ Lymphocyte transformation test; $\mathrm{mAb}$ $=$ Monoclonal antibodies; MELISA ${ }^{\circledR}=$ Memory lymphocyte immuno-stimulation assay; PBMC = Periph- eral blood mononuclear cells; PHA-P = Phytohemagglutinin; $\mathrm{PT}=$ Patch test; $\mathrm{ROC}=$ Receiver operating characteristic; $\mathrm{SPT}=$ Strip patch test

\section{INTRODUCTION}

Since its inauguration in 1895 by Jadassohn [1], the patch test (PT) is believed to be the "gold standard" in the diagnosis of allergic contact dermatitis (ACD). However, the method of patch testing has repeatedly been questioned [2-6] for its limited validity and reproducibility and it is therefore by no means uniformly accepted as a reliable test method. As a variant of patch testing, tape stripping the skin prior to patch testing was first mentioned in 1953 by Spier and Natzel [7]. Since then, the strip patch test (SPT) is used in some places to obtain more valid and reliable test results [8-13].

Although a non-in vivo test would be desirable, to date, none of the established in vitro tests for the diagnosis of ACD (e.g., LTT, MELISA ${ }^{\circledR}$, ELISpot assay) fulfils the requirements of a practical test with sufficient validity and reliability [5, 14-17]. An advanced approach is the flow cytometric analysis of CD69 up-regulation on $\mathrm{T}$ lymphocytes in vitro [1821]. As previously reported, metal ions released from orthopedic implants in patients with metal prostheses increased the expression of CD69 activation antigen on CD3+ lymphocytes considerably and flow cytometry proved to be an easy and reliable method for detection [19]. The expression of the CD69 activation antigen on CD4+ T cells after stimulation with drugs has been just recently evaluated in a pilot study and shown to discriminate well between drug-allergic and non-allergic patients [21].

Based on the additional findings of Moed et al. [22] that nickel-allergic patients are characterized by a CD4+ CD45RO+ CLA+ T cell phenotype, we designed a study to analyze the extent of CD69 activation antigen expression on CD4+ CLA $+\mathrm{T}$ cells in nickel-sensitive and non-nickel-sensitive patients using flow cytometry. Our flow cytometric assay would offer some advantages over the classical LTT, as it provides results after $72 \mathrm{~h}$ instead of 7 days and does not require ${ }^{3} \mathrm{H}$-thymidine incorporation. We measured asso- 
ciation between CD69 up-regulation on CD4+ CLA+ $\mathrm{T}$ cells on the one hand and PT, SPT, and clinical history on the other hand.

\section{Methods}

The prospective, investigator-blinded, clinical study was approved by the ethics committee of the Medical Faculty of the Ruhr University Bochum. Procedures were explained in detail to all patients, who signed informed consent forms prior to participation.

\section{Patient Recruitment Procedure}

Patients had to be at least 18 years old and had to have clinically normal skin. Exclusion criteria were pregnancy, lactation, intake of immunosuppressive or immune modulating drugs such as glucocorticoids or cyclosporine, topical use of glucocorticoids at the back, and intense UV exposure on the back within the last 4 weeks prior to patch testing, respectively.

To optimize statistical power and discrimination between PT and SPT, patients were selected according to their PT and SPT results to nickel sulfate 5\% pet. following a prespecified protocol. This aimed for half of the study patients being PT positive and SPT positive, respectively. We defined patients as being "nickel-sensitive" if either one of the patch tests was positive, or if the clinical history indicated a delayed-type sensitization (DTS).

To avoid the influence of a positive PT or SPT, blood samples were taken at least 6 weeks after patch testing [22]. At the time of blood sample collection, in any patient symptoms of DTS had subsided. All blood tests were obtained between 2009-03-09 and 2009-0706; they were coded and performed within $2 \mathrm{~h}$. Patients received a small allowance for taking of blood samples.

\section{Patch Test and Strip Patch Test}

PT was performed according to standard methodology [23]. SPT was performed according to our standardized method described in details elsewhere [11, $12,24]$. Tape stripping was carried out with a $3 \mathrm{M}^{\mathrm{TM}}$ Blenderm ${ }^{\mathrm{TM}}$ surgical tape $\left(3 \mathrm{M}^{\mathrm{TM}}\right.$ Medica, $3 \mathrm{M}$ Deutschland $\mathrm{GmbH}$, Neuss, Germany; metric $25 \mathrm{~mm} \times 4.5 \mathrm{~m}$ ); any body hair was removed before with a $3 \mathrm{M}^{\mathrm{TM}}$ Clipper.

Patients were tested on the upper back with nickel sulfate $5 \%$ pet. supplied by HERMAL, Reinbek, Germany. Small Finn Chambers on Scanpor ${ }^{\circledR}$ (Epitest Ltd Oy, Tuusula, Finland) were used. PT and SPT were applied to the left and right side of the upper back with one randomly chosen side tape stripped for the SPT. Other patch test batteries were applied conventionally as appropriate to the patient's presenting complaints. Tests were uniformly removed after 24 hours and readings were routinely performed at D1 $(24 \mathrm{~h})$ and D3 (72 h). Positive results are reported based on the second reading. The tests results were graded using the classification system of the ICDRG [25] and dichotomized for statistical analysis. All "+", " $++"$, and "+++" positive results were summarized as positive responses, whereas doubtful "?/(+)", irritant "IR", and negative "-" reactions counted as negative responses.

\section{Clinical History}

DTS to nickel sulfate was determined following an algorithm that used information on four questions on (i) intolerance to fashion jewelry, (ii) jeans button eczema, (iii) hand eczema by working galvanic processes, and (iv) sensitization proved by PT in the past. Patients were classified as to whether or not they had a DTS to nickel sulfate based on their responses ("sensitized" by definition if $\geq 2$ questions were positively answered) prior to undergoing the patch tests.

\section{PBmc Isolation And Culture}

Twenty milliliters of blood was collected from all the patients and placed into two BD Vacutainer ${ }^{\circledR} \mathrm{CPT}^{\mathrm{TM}}$ cell preparation tubes with sodium heparin (Becton, Dickinson and Company, NJ, USA; No. 362753). PBMC were isolated from heparinized blood samples by density centrifugation on Heraeus Megafuge 16R (Thermo Scientific, MA, USA) for $20 \mathrm{~min}$ at 1800 $\times \mathrm{g}$. The collected PBMC were washed twice with D-PBS (Invitrogen Corporation, CA, USA; No. 14190 ) by centrifugation for $6 \mathrm{~min}$ at $250 \mathrm{xg}$ and then resuspended in culture medium composed of RPMI-1640 medium supplemented with L-glutamine $^{-}$ (SIGMA-Aldrich company, Ayrshire, UK; No. R8758), $10 \%$ autologous serum, and 1\% stabilized antibiotic antimycotic solution (SIGMA-Aldrich company; No. A5955). PBMC suspensions at a concentration of $1 \times 10^{6}$ viable cells $/ \mathrm{ml}$ were prepared; cell viability was measured by exclusion of $0.4 \%$ trypan blue.

PBMC $(100 \mu \mathrm{l})$ were plated in duplicate $(1 \times$ $10^{5} /$ well) in 96-well flat-bottomed plates (Greiner Bio-one GmbH, Essen, Germany). Stimuli were: $100 \mu \mathrm{l}$ of fresh culture medium as negative control (composed as mentioned above), $100 \mu \mathrm{l}$ of each non-cytotoxic nickel sulfate concentration $\left(10^{-5} \mathrm{M}\right.$, $2.6 \mu \mathrm{g} / \mathrm{ml} ; 10^{-6} \mathrm{M}, 262.8 \mathrm{ng} / \mathrm{ml} ; 10^{-7} \mathrm{M}, 26.3 \mathrm{ng} / \mathrm{ml}$ ), and $100 \mu \mathrm{l}$ of each PHA-P concentration as positive controls $(5.0 \mu \mathrm{g} / \mathrm{ml} ; 2.5 \mu \mathrm{g} / \mathrm{ml} ; \quad$ SIGMA-Aldrich company, Ayrshire, UK; No. L1668). Cell cultures were incubated at $37{ }^{\circ} \mathrm{C}$ in a humidified $95 \%$ air/ $5 \% \mathrm{CO}_{2}$ atmosphere for $72 \mathrm{~h}[21,26]\left(\mathrm{CO}_{2}\right.$ water jacketed incubator NU 4500E; NuAire Inc., MN, USA).

The raw material nickel sulfate hexahydrate (NiSO ${ }_{4} 6 \mathrm{H}_{2} \mathrm{O}$; CAS No. 10101-97-0) used for the fabrication of the patch test substance nickel sulfate $5 \%$ pet. was purchased from HERMAL, Reinbek, Germany. The freshly prepared stock solution of nickel sulfate $\left(10^{-2} \mathrm{M}, 2.6 \mathrm{mg} / \mathrm{ml}\right)$ was centrifuged and filtered onto $0.22 \mu \mathrm{m}$ pore filter in order to eliminate any particulate residual. In preliminary sets of samples $(\mathrm{n}=12$; data not shown) higher concentrations of nickel sulfate $\left(10^{-3} \mathrm{M}, 262.8 \mu \mathrm{g} / \mathrm{ml} ; 10^{-4} \mathrm{M}, 26.3 \mu \mathrm{g} / \mathrm{ml}\right)$ showed cytotoxic effects whereas lower concentrations $\left(10^{-8} \mathrm{M}, 2.6 \mathrm{ng} / \mathrm{ml} ; 10^{-9} \mathrm{M}, 262.8 \mathrm{pg} / \mathrm{ml}\right.$ ) showed no effects. 
Flow Cytometric Analysis of CD69 UP-REGULATION

After incubation the PBMC were washed with D-PBS and then surface stained for $30 \mathrm{~min}$ in the dark at $4{ }^{\circ} \mathrm{C}$ with a suspension of $\mathrm{mAb}$ for detection of CD69-activated CD4+ CLA + T cells: anti-CLA-FITC/antiCD4-PE-Cy7/anti-CD45-PerCP-Cy5.5/anti-CD69APC/anti-CD3-APC-H7 (BD Biosciences, CA, USA).

The proportion of CD45/CD3/CD4/CLA/CD69positive PBMC was evaluated on $\geq 20,000$ events within the scatter gate CD3 using a 3 laser $(488,405,633$ nm) 8 parameter FACSCanto $^{\text {TM }}$ II flow cytometer with FACSDiva $^{\text {TM }}$ software (BD Biosciences, CA, USA). The results were normalized for heterogeneous background proliferation. Thus, a ratio ("activation index", AI) [19] between the percentage of CD45/ CD3/CD4/CLA/CD69-positive cells stimulated with nickel sulfate and the percentage of the control cells stimulated with culture medium only was expressed. An AI value $<0.9$ may be interpreted as "low activation", $\geq 0.9$ and $<2$ as "normal activation", and $\geq 2$ as "high activation"/"positive" [19, 21, 26]. We used the maximum AI across the three nickel sulfate concentrations $\left(10^{-5} \mathrm{M}, 10^{-6} \mathrm{M}, 10^{-7} \mathrm{M}\right)$ for statistical analysis.

\section{BLINDING}

The reading physician (H.D.) was blinded with respect to (i) the clinical history and (ii) which side of the patient's back was tape stripped. Unblinding was done after the second reading for clinical interpretation of test results. The laboratory technician performing the flow cytometric assay of CD 69 up-regulation (S.H.) was blinded with respect to (i) the clinical history and (ii) the patch test results.

\section{STATISTICAl ANALYsis}

For descriptive purposes, we report categorical variables as absolute (relative) frequencies, and continuous variable as median (min-max, Q1, Q3). To measure association between flow cytometric assay of CD 69 upregulation (maximum $\mathrm{AI}$ ) on the one hand and $\mathrm{PT}$, SPT, and clinical history on the other hand, we applied ROC analysis and the corresponding c statistic measuring the area under the ROC curve. The c statistic can be conveniently interpreted as the probability of a PT positive (or SPT positive, or clinical history positive) patient having a larger maximum AI, than a PT negative (or SPT negative, or clinical history negative) patient. Thus, values of the c statistic of 0.5 corresponds to purely random association, whereas values of 0 or 1 correspond to a perfect association. All c statistics are given with the respective 95\% CIs. Statistical analyses were conducted with SAS ${ }^{\circledR}$ (SAS Institute, Cary, NC, USA), Version 9.2., where the newly introduced ROC statement in the LOGISTIC procedure allows ROC analysis and calculates CIs for the c statistic.

\section{RESULTS}

Demographic and clinical characteristics of the 85 nickel-sensitive $(\mathrm{n}=44 ; 51.8 \%$ ) and non-nickel-sensi-
Table 1. Demographic and clinical patient characteristics $(\mathrm{N}=$ 85).

\begin{tabular}{ll}
\hline Characteristic & Value \\
\hline Age (years), median (min-max, Q1, Q3) & $53(18-75,4$ \\
Sex, n (\%) & \\
female & $60(70.6)$ \\
male & $25(29.4)$ \\
Fitzpatrick skin phototype, n (\%) & \\
I & $1(1.2)$ \\
II & $64(75.2)$ \\
III & $19(22.4)$ \\
IV & $1(1.2)$ \\
V, VI & $0(0)$
\end{tabular}

CD69 up-regulation by $\mathrm{Ni}$ stimulation

$\mathrm{AI}^{*}$, median (min-max, Q1, Q3)

$2.5(0.3-61.0,1.5,5.7)$

Positive skin reaction to $\mathrm{Ni}, \mathrm{n}(\%)$

in PT on D3

in SPT on D3

$21(24.7)$

$37(43.5)$

Positive clinical history to $\mathbf{N i}, \mathrm{n}(\%) \quad 31(36.5)$

$\mathrm{Q} 1=25^{\text {th }}$ percentile; $\mathrm{Q} 3=75^{\text {th }}$ percentile; $\mathrm{Ni}=$ nickel sulfate; D3 $=$ second reading at $72 \mathrm{~h} ; *=\mathrm{AI}$ is defined as the maximum AI across the three nickel sulfate concentrations $\left(10^{-5} \mathrm{M}\right.$, $\left.10^{-6} \mathrm{M}, 10^{-7} \mathrm{M}\right)$.

tive patients ( $\mathrm{n}=41 ; 48.2 \%$ ) enrolled in the study are summarized in Table 1.

\section{Association of the Flow Cytometric Assay of CD 69 Up-regulation Versus Pt, Spt And Clinical History}

There was no association between the extent of CD69 activation antigen expression on CD4+ CLA+ T cells in vitro and PT, SPT, and clinical history. C statistics differed only marginally from the value of no association, which is 0.5 (Fig. $1 \mathrm{~A}-\mathrm{C}$ ).

\section{Prediction of Sensitization by Pt Spt, and Flow Cytometric Assay of CD 69 Up-regulation}

In relation to the clinical history, PT alone predicts satisfyingly the sensitization to nickel sulfate ( $c=0.69$, 95\% CI: 0.59-0.79). The prediction accuracy could be improved significantly to good by additionally performing the SPT ( $c=0.83$, 95\% CI: 0.74-0.92). However, no further diagnostic information could be gathered by additionally using the results of the flow cytometric assay of CD69 up-regulation on CD4+ CLA+ T cells (c $=0.83,95 \%$ CI: $0.74-0.93$ ).

\section{Discussion}

In the present study the flow cytometric assay of CD69 up-regulation on CD4+ CLA+ T cells could not predict neither a positive PT or SPT result nor a positive clinical history to nickel sulfate (Fig. 1 A-C). On the contrary, we found relevant improvements in prediction of clinical history-based nickel sensitization beyond PT by the SPT, but not by our flow cytometric assay. 

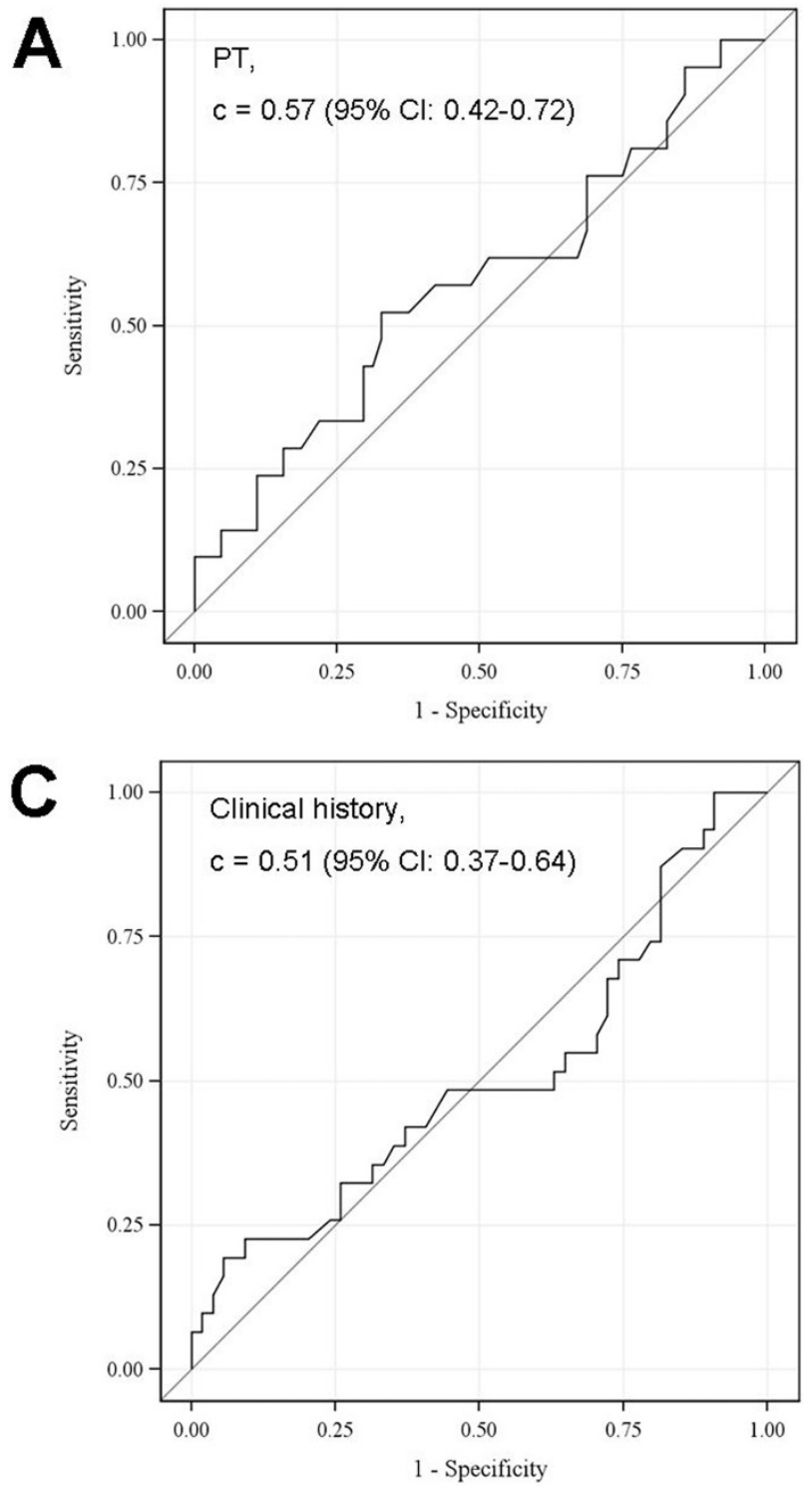

In the in vitro tests so far, the response of PBMC to nickel sulfate generally appeared to be variable, and at best weakly correlated with the PT response [27, 28]. Association with the SPT response was never investigated before. Nevertheless, the PT is usually the reference standard against which in vitro tests are compared [14, 15, 27, 29], despite its numerous methodological drawbacks (e.g., false-positive and false-negative test results) [20]. Only few authors have like us additionally focused on assessing association of in vitro tests and clinical history [30].

\section{Methodological Aspects Concerning the DisCORDANT RESULTS}

First, the basis of the study was the observation of Moed et al. [22] that CD4+ CD45RO+ CLA+ and not $\mathrm{CD} 8+\mathrm{T}$ cells proliferate and produce cytokines in response to nickel. Additionally, they confirmed that CLA can serve as a preselection marker to improve detection of antigen-specific $\mathrm{T}$ cells in patients with suspected ACD. In the initial sensitization phase, naive $T$ cells in the regional lymph nodes are primed by local antigen-bearing DC and expand clonally $[31,32]$. By

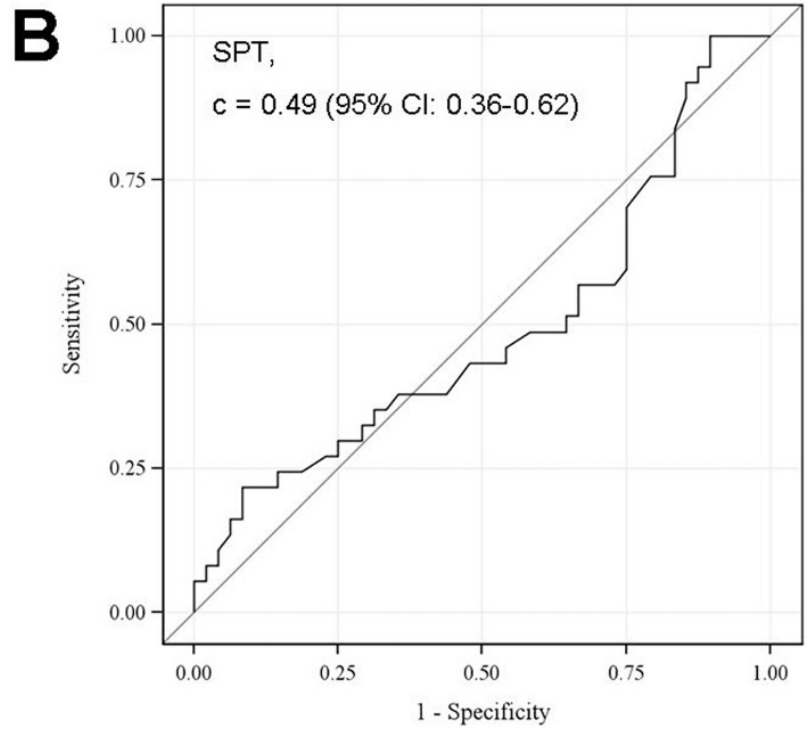

Fig. 1. Area under the ROC curve (c statistic) for flow cytometric assay of CD69 up-regulation predicting in vivo test results (A, B) and clinical history (C).

expressing CLA which is a specific chemokine receptor involved in lymphocyte homing to skin, these $\mathrm{T}$ cells are then enabled to circulate throughout the blood into the dermis [19, 33, 34]. In the following elicitation phase, the T-cell mediated ACD reaction occurs normally $24-72 \mathrm{~h}$ after re-exposure to antigen [32]. Within the first 24 hours, the integral membrane protein CD69 is transiently expressed on the antigenspecific $\mathrm{T}$ cells and acts as a co-stimulator for $\mathrm{T}$ cell activation and proliferation. Thus, it was reasonable to postulate that an expression assay of CD69 on CD4+ CLA + $\mathrm{T}$ cells is a promising readout test of DTS. However, we omitted staining with anti-CD45ROFITC due to a too high restriction resulting in a small number of analyzable T cells. Second, it is reported that nickel sulfate has in contrast to other metal salts non-specific stimulatory properties in vitro which still is a major problem $[14,15,17]$. In our study we obtained the raw material of nickel sulfate hexahydrate straight from the production process of the patch test substance and the highest concentration used for stimulation was $2.6 \mu \mathrm{g} / \mathrm{ml}$ [14]. Thus, a cytotoxic or mitogenic effect of the nickel concentrations should be unlikely because concentrations of nickel sulfate greater 
than $5.0 \mu \mathrm{g} / \mathrm{ml}$ were found to stimulate cells from certain non-sensitized individuals, i.e. induce false positive test results $[27,29]$. Additionally, from our data (median AI $=2.5$, Table 1 ) it is unlikely that the flow cytometric assay of CD69 up-regulation on CD4+ CLA $+\mathrm{T}$ cells produced false negative test results because of a too weak activation of $\mathrm{T}$ cells by nickel sulfate [21].

\section{Biological Aspects Concerning the Discordant RESUlts}

First, Beeler et al. [21] showed only recently that flow cytometric measurement of CD69 up-regulation on CD4+ T cells is a promising alternative to LT'T in diagnosing drug hypersensitivity. However, they reported that the high frequency of activated $\mathrm{T}$ cells could not be explained by a rapid expansion of few drug reactive $\mathrm{T}$ cells and that only up to $5 \%$ of $\mathrm{CD} 69+\mathrm{T}$ cells reacted to drug stimulation with cytokine production. Thus, they distinguished between two subsets of $\mathrm{T}$ cells: (i) few drug-reactive $\mathrm{T}$ cells, which are most likely identical to the proliferating and/or cytokine-secreting $\mathrm{T}$ cells, and (ii) many drug-activated "bystander" 'T cells, which reacted to cytokines secreted by the "truly" drug-specific T cells. From this they argued that this does not affect the specificity of the test, but substantially increases its sensitivity. Second, a positive in vitro test together with a negative PT or SPT could be explained by the fact that nickel-specific $\mathrm{T}$ cells were found in patients without nickel allergy [14]. On the contrary, there is a positive PT or SPT and a negative in vitro test which might theoretically be due to nickel-specific cells homing to the site of local skin reaction. Finally, different $\mathrm{T}$ cell subsets may be activated in vitro and in vivo upon contact with nickel sulfate and could explain non-correlating test results [32].

\section{CONCLUSION}

The flow cytometric assay of CD69 up-regulation on CD4+ CLA + T cells as an alternative to existing in vitro tests is no help for diagnosing ACD to nickel. In consequence, the combination of clinical history and patch test results continues to be the basis for the diagnosis of ACD [17]. Further studies are needed in search of an innovative in vitro test method with sufficient discrimination between allergic and non-allergic patients [26].

Conflict of interests statement: All authors declare that they have no personal funding.

Acknowledgments: The study was supported with test material (Blenderm ${ }^{\mathrm{TM}}$ surgical tapes, Clippers) for the strip patch test by $3 \mathrm{M}^{\mathrm{TM}}$ Medica, $3 \mathrm{M}$ Deutschland GmbH, Neuss, Germany. We thank the patients for their participation in our study.

\section{REFERENCES}

1. Jadassohn J. Zur Kenntnis der medicamentösen Dermatosen. Verhandlungen der Deutschen Dermatologischen Gesellschaft, 5. Kongreß, Graz, 1895. Braumüller, Wien 1896; 103-129.
2. Nethercott JR. Practical problems in the use of patch testing in the evaluation of patients with contact dermatitis. Curr Probl Dermatol 1990; 2: 97-123.

3. Nethercott JR. Sensitivity and specificity of patch tests. Am J Contact Dermat 1994; 5: 136-142.

4. Shuster S. Patch-test sensitivity and reproducibility in individuals and populations. Am J Contact Dermat 1992; 3: 74-78.

5. Belsito DV, Storrs FJ, Taylor JS, Marks Jr JG, Adams RM, Rietschel RL, Jordan WP, Emmett EA. Reproducibility of Patch Tests: A United States Multicenter Study. Am J Contact Dermat 1992; 3: 193-200.

6. Brasch J, Henseler T, Aberer W, Bäuerle G, Frosch PJ, Fuchs T, Fünfstück V, Kaiser G, Lischka GG, Pilz B, Sauer C, Schaller J, Scheuer B, Szliska C. Reproducibility of patch tests: A multicenter study of synchronous leftversus right-sided patch tests by the German Contact Dermatitis Research Group. J Am Acad Dermatol 1994; 31: 584-591.

7. Spier HW, Natzel R. Chromatallergie und Zementekzem. Gewerbedermatologischer und analytischer Beitrag. Hautarzt 1953; 4: 63-65.

8. Spier HW, Sixt I. Untersuchungen über die Abhängigkeit des Ausfalles der Ekzem-Läppchenproben von der Hornschichtdicke. Quantitativer Abriß-Epikutantest. Hautarzt 1955; 6: 152-159.

9. Frosch PJ, Weickel R, Schmitt T, Krastel H. Nebenwirkungen von ophthalmologischen Externa. Z Hautkr 1988; 63: 126-136.

10. Fernandes MFM, de Mello JF, Pires MC, Vizeu MCM. Comparative study of patch test using traditional method vs. prior skin abrading. J Eur Acad Dermatol Venereol 2007; 21: 1351-1359.

11. Dickel H, Kamphowe J, Geier J, Altmeyer P, Kuss O. Strip patch test vs. conventional patch test: investigation of dose-dependent test sensitivities in nickel- and chromium-sensitive subjects. J Eur Acad Dermatol Venereol 2009; 23: 1018-1025.

12. Dickel H, Scola N, Altmeyer P. The strip patch test - indication in occupational dermatology demonstrated with a case history. J Dtsch Dermatol Ges 2009; 11: 965-967.

13. Lachapelle JM, Maibach HI. Patch Testing and Prick Testing - A Practical Guide (Official Publication of the ICDRG), 2nd Auflage, Springer-Verlag, Berlin Heidelberg, 2009.

14. Cederbrant K, Hultman P, Marcusson JA, Tibbling L. In vitro lymphocyte proliferation as compared to patch test using gold, palladium and nickel. Int Arch Allergy Immunol 1997; 112: 212-217.

15. Cederbrant K, Anderson C, Andersson T, MarcussonStahl M, Hultman P. Cytokine production, lymphocyte proliferation and T-cell receptor Vbeta expression in primary peripheral blood mononuclear cell cultures from nickel-allergic individuals. Int Arch Allergy Immunol 2003; 132: 373-379.

16. Brehler R, Merk H. In-vitro-Tests zum Nachweis von Kontaktallergien. Hautarzt 2005; 56: 1141-1143.

17. Traidl-Hoffmann C, Ring J. Is there an in vitro test for type IV allergy discriminating between sensitization and allergic disease? Clin Exp Allergy 2008; 38: 1412-1415.

18. Werfel T, Boeker M, Kapp A. Rapid expression of the CD69 antigen on T cells and natural killer cells upon antigenic stimulation of peripheral blood mononuclear cell suspensions. Allergy 1997; 52: 465-469.

19. Granchi D, Ciapetti G, Savarino L, Stea S, Filippini F, Sudanese A, Rotini R, Giunti A. Expression of the CD69 activation antigen on lymphocytes of patients with hip prosthesis. Biomaterials 2000; 21: 2059-2065.

20. Avgustin B, Kotnik V, Skoberne M, Malovrh T, Skralovnik-Stern A, Tercelj M. CD69 expression on CD4+ T lymphocytes after in vitro stimulation with tuberculin is 
an indicator of immune sensitization against Mycobacterium tuberculosis antigens. Clin Diagn Lab Immunol 2005; 12: 101-106.

21. Beeler A, Zaccaria L, Kawabata T, Gerber BO, Pichler WJ. CD69 upregulation on $\mathrm{T}$ cells as an in vitro marker for delayed-type drug hypersensitivity. Allergy 2008; 63: 181-188.

22. Moed H, Boorsma DM, Stoof TJ, von Blomberg BME, Bruynzeel DP, Scheper RJ, Gibbs S, Rustemeyer T. Nickel-responding $\mathrm{T}$ cells are CD4+ CLA+ CD45RO+ and express chemokine receptors CXCR3, CCR4 and CCR10. Br J Dermatol 2004; 151: 32-41.

23. Schnuch A, Aberer W, Agathos M, Becker D, Brasch J, Elsner P, Frosch PJ, Fuchs T, Geier J, Hillen U, Löffler H, Mahler V, Richter G, Szliska C, für die Deutsche Kontaktallergie-Gruppe. Durchführung des Epikutantests mit Kontaktallergenen. Leitlinien der Deutschen Dermatologischen Gesellschaft (DDG) und der Deutschen Gesellschaft für Allergie und klinische Immunologie (DGAKI). J Dtsch Dermatol Ges 2008; 6: 770-775.

24. Dickel H, Bruckner TM, Erdmann SM, Fluhr JW, Frosch PJ, Grabbe J, Löffler H, Merk HF, Pirker C, Schwanitz HJ, Weisshaar E, Brasch J. The "strip" patch test: results of a multicentre study towards a standardization. Arch Dermatol Res 2004; 296: 212-219.

25. Fregert S. Manual of contact dermatitis, 2nd Auflage, Munksgaard, Copenhagen, 1981.

26. Lochmatter P, Beeler A, Kawabata TT, Gerber BO, Pichler WJ. Drug-specific in vitro release of IL-2, IL-5, IL-13 and IFN-gamma in patients with delayed-type drug hypersensitivity. Allergy 2009; 64: 1269-1278.

27. Everness KM, Gawkrodger DJ, Botham PA, Hunter JAA. The discrimination between nickel-sensitive and nonnickel-sensitive subjects by an in vitro lymphocyte transformation test. Br J Dermatol 1990; 122: 293-298.

28. Pate GE, Wu V, Webb JG. Nickel allergy: lack of correlation between systemic TH1 immune response and skin patch testing. J Invasive Cardiol 2005; $17: 574$.
29. Kimber I, Quirke S, Cumberbatch M, Ashby J, Paton D, Aldridge RD, Hunter JAA, Beck MH. Lymphocyte transformation and thiuram sensitization. Contact Dermatitis 1991; 24: 164-171.

30. Lindemann M, Böhmer J, Zabel M, Grosse-Wilde H. ELISpot: a new tool for the detection of nickel sensitization. Clin Exp Allergy 2003; 33: 992-998.

31. Gober MD, Gaspari AA. Allergic contact dermatitis. In: Nickoloff BJ, Nestle FO: Dermatologic immunity. Basel Freiburg Paris London New York Bangalore Bangkok Shanghai Singapore Tokyo Sydney: Karger, 2008: 1-26.

32. Vocanson M, Hennino A, Rozières A, Poyet $G$, Nicolas JF. Effector and regulatory mechanisms in allergic contact dermatitis. Allergy 2009; 64: 1699-1714.

33. Schoenberger SP, Crotty S. Immunologic memory. In: Paul WE: Fundamental immunology. 6th ed. Philadelphia Baltimore New York London Buenos Aires Hong Kong Sydney Tokyo: Lippincott Williams \& Wilkins, a Wolters Kluwer business, 2008: 862-897.

34. Murphy PM. Chemokines. In: Paul WE: Fundamental immunology. 6th Auflage. Philadelphia Baltimore New York London Buenos Aires Hong Kong Sydney Tokyo: Lippincott Williams \& Wilkins, a Wolters Kluwer business, 2008: 804-833.

Received: November 10, 2009 / Accepted: March 1, 2010

Address for correspondence:

Heinrich Dickel, MD

Department of Dermatology and Allergology

Ruhr University Bochum

St. Josef-Hospital

Gudrunstrasse 56

44791 Bochum, NRW

Germany

Tel.: +49-234-509-3448

Fax: +49-234-509-3451

E-mail: h.dickel@klinikum-bochum.de 